\section{E A Institute of \\ YK Business Administration \\ 页下 \\ Karachi \\ Leadership and Ideas for Tomorrow}

\section{Business Review}

Volume 3 Issue 2 July-December 2008

7-1-2008

\title{
Pilot study of 8 SMEs in Pakistan
}

Ejaz Mian

Universiti Sains Malaysia, Malaysia

Follow this and additional works at: https://ir.iba.edu.pk/businessreview

Part of the Entrepreneurial and Small Business Operations Commons

(c) (i)

This work is licensed under a Creative Commons Attribution 4.0 International License.

\section{Recommended Citation}

Mian, E. (2008). Pilot study of 8 SMEs in Pakistan. Business Review, 3(2), 1-26. Retrieved from https://doi.org/10.54784/1990-6587.1157 


\title{
CASE STUDIES
}

\section{Pilot Study of 8 SMEs in Pakistan}

\author{
Ejaz Mian \\ Universiti Sains Malaysia, Malaysia
}

\begin{abstract}
These cases study small firms (with 1-50 employees) in Pakistan to determine marketing factors that lead to success. Information is gathered through in-depth interviews with owner-managers on their premises. Convenience sampling is used within the city of Karachi. Firms included relate to production, and services (including retail). It was found that most of the firms are not marketing oriented and they do not understand marketing. Thus they will benefit from some kind of marketing training conducted by the government or through their own resources.
\end{abstract}

Keywords: Small Firms; Marketing Philosophy; Strategic Aspects; Entrepreneurial Marketing.

CASE NO. 3

FASHION VIBES

(Small enterprise with 20 employees)

\section{HISTORY}

Fashion Vibes (FV) started ten years ago by Faisal Mian an entrepreneur with corporate background. Faisal has rich experience of working as marketing manager with the MNC Berger Paints and later with Lasani Wood, a synthetic wood making company. He has an MBA degree and a B.Com to his credit. Due to the entrepreneurial instinct in him he later moved to his own business. He wanted to be the master of his own fate and make more money using the creative freak in his psyche. In this he was ably helped by his medical doctor wife who gave up the lucrative medical profession to take care of the couple's three sons and to help him in his business.

FV started as a bridal wear house catering to the requirements of the up market in Karachi for bridal wear needs. Though Faisal did not have any background in such fashion clothing he quickly acquired it by his keen observation and with help of his wife. His designs were original and expensive. Soon it was realized that he could not sustain himself on the bridal wear as there was not sufficient volume in this product. So he moved on to a niche market of night wear. 
It was realized that there existed an unrecognized need for night wear in Karachi in upper and upper middle class consumers. This need was more pronounced at the time of weddings when the couples needed to make a fashion statement to each other. There was a need for locally made night wear of international quality available at prices below that of the imported ones. And there was also the possibility in the local designs to involve the customer by including her/his imagination in the design of the garment. Designer wear is a need long felt in Pakistan in a segment of the population who have money and want to stand out from the rest. In Pakistan there is little opportunity for expression of self especially for women. Clothing thus plays its part in self expression and women use their creativity to make a statement about them and to stand out from the crowd. Thus the market for designer wear. It is also a part of the culture that middle and upper class and sometimes even lower class women would rather be found dead than wear a dress twice to the same gathering. This would be considered extreme humiliation for them. This means each new occasion must have a new dress.

When market of night wear moved toward saturation FV thought of new ideas as to how to sustain themselves. Kurti was then the product to think of. The word 'kurti' has been coined by Faisal as a shorter version of kurta which men wear as an upper part of a traditional Pakistani (and Indian) dress worn predominantly by the Muslims of the subcontinent. Kurti is the modern female version of the same. It is 'short, sweet and to the point.' Kurti immediately struck chord with the young and upcoming fashion conscious westernized females. Various designs were made and further additions were possible and suggested by the clients. Prices were high but still affordable for those who sought to wear this kind of apparel to stand out. Various fabrics and designs including handiwork and embroidery were created.

Now after passage of almost ten years in the business Faisal is thinking what to do next. The business seems stable but not growing much and to survive he needs ideas for new saleable products. So what is the market doing? This question can only be answered by market research. There is no formal market research done. Though FV has a fair idea of what the market wants all this is based on feeling and judgment. And the communication flow is one way i.e. from the seller to the prospect.

\section{MACROENVIRONMENT}

\section{CULTURAL}

Pakistan remains a moderate Islamic state where most of the population, i.e. $97 \%$ are Muslims. East and west can be seen side by side everywhere. According to Christina Lamb in her book 'Waiting for Allah' nothing has been settled in the country. All basic issues are still open to debate. Should the country be secular or ideological state? Should women be equal to men? Is religion a private or a public 
issue? What does religion say on various matters? These and such other issues are still being discussed and there is no agreement. One of the prime issues that challenge the fancy of the Mullah is the attire of women. What should women wear? And how modest should women's' dress be?

In midst of such highly charged debates thrives the real culture of Pakistan. It is the net result of the 5000 years of the Indus Valley Civilization later subject to the Hindu and then to the Muslim religions and traditions. Historically Muslims had been the dominant culture ever since the invasion of India by Muhammad Bin Qasim from Arabia who brought Islam into India some 1200 years ago. Later the Mughals came and conquered India and established the great Mughal empire which lasted 300 years. This era gave to India its rich cultural heritage with a dominant Persian flavor. The Mughals were Persian speaking immigrants from Central Asia. Since the fall of the Mughal Empire and the advent of the rule of the East India Company, British culture became the dominant culture and brought with itself the English language, dress, food and style. This then became the style of the elite of the subcontinent. Even after departure of the British in 1947 and partition of the sub-continent into India and Pakistan, the culture left behind by the British continues to be the dominant culture in Pakistan. The more westernized one is the more highly he is looked upon in society. As a matter of fact being westernized is a sign of progress and success. It is in this context that the culture of Pakistani women and their dress has to be understood. There is no 'Pakistani dress' per se. It has never been defined. Just like there is nothing strictly defined as Pakistani food. It is really a mix and a hodge podge of the various influences of history, conflicts, climate and affluence.

Thus the Pakistani woman can be led to dress in any way as long as it does not cross the basic value guidelines. Thus there is a great scope of leadership in Pakistani women's fashion including the newly emerging executive attire. This includes clothing for the Pakistani woman who appears on the media, works as banker, journalist, doctor, professor, teacher, nurse, secretary and much more.

\section{ECONOMIC}

The fashion market is for the urban middle and upper class women. Only they can afford the luxury of playing to their whims. It is they who have the disposable income available from their husbands or their combined salaries to spend in such joyful spending. There is a substantial clientele available to the fashion industry to cater to. Many women have such purchasing power as to buy one or more dresses and shoes weekly. And this affords them a hobby and a pastime. 


\section{COMPETITIVE}

The fashion market has a lot of competition. It is a big industry now. New boutiques are opening weekly and many also go out of business or change their product line. Women's fashion apparel is catered to through various sources. The upper most is the foreign outlets located in Europe and Dubai where women go for shopping. This is for the very top class. Most others cannot afford this. It needs resources to travel abroad and to go for shopping trips in this way. Yet this is one option for many in the top class. Some others buy foreign manufactured clothing and fabrics within the country from some formal and informal sources of import and thus are able to satisfy their desire for the 'imported' merchandise.

For the one who cannot or will not go for the foreign made stuff there are the local fashion houses which fill the gap. These are in shape of boutiques selling ready made to tailor made garments made according to the choice of the buyer. And in the latter the buyer sometimes becomes part of the creative process. This is a source of great satisfaction for the buyer as she feels she has created the design herself and is sure no one else has it. It is here the set ups like Fashion Vibes find a place for themselves to fill a gap. Many of the upper middle class women end up themselves doing the same business from their basements. Sometimes importing ready made products and selling it through networks of friends and friends' friends. They may gradually grow up into full fledged 'fashion designers' or carry on just like that or even fade away when the excitement or the energies start dwindling or when the going gets tough.

But the serious types of fashion houses continue and constantly change their offers to cater to the rather fickle type of customer. To survive they have to have an in-market outlet. Location is crucial. As we say in marketing, in retail business there are three things which are very important: location, location and location. Prime location for the upper market in Karachi is the Zamzama area in the Defense Society commercial zone. This is in the center of Defense and Clifton the two most posh areas of Karachi. It is here that most of the women's' fashion wear outlets are. And it is here that FV is located. Their stitching unit is located at a distance of about $8 \mathrm{~km}$ toward the main airport road which is the main artery for Karachi. It is housed in the third floor of the family house of Mian family in PECH Society.

There has been a mushroom growth of new set ups in garments mostly comprising of those who are copy cats. They see a certain product moving in the market and decide to enter, and play on prices. Expiry rate of such ventures too is quite high as is typical of all small business. 


\section{MICROENVIRONMENT}

Faisal has a work force of about 15 to 20 employees at any one time including top of the line tailors from the industry. Most of his work is now moving towards tailor made dresses of all types. There are two experts of embroidery work who stitch high class embroidered dresses for weddings and other fancy occasions. Distance of the stitching unit from the sales outlet is a small hindrance but not a big one. The sales outlet is managed and run by a competent lady who has worked with the company now for almost 8 years. And she has proven to be a trust worthy worker for Faisal. It enables him to concentrate on his stitching unit and supervise the workers who tend to waste time if he is not around. Even incentive based payment system has not been successful in making them self starters. When incentive is offered their emphasis shifts from quality to quantity. Faisal has to an extent standardized the production requirements of each worker as to what he is expected to produce in a day.

Financing has been a limiting factor. Faisal has been thinking for a long time to diversify into some fruitful ventures but for this to happen substantial capital is required and it is not easily available. In the present business the technology that is required is quite basic and $\mathrm{FV}$ already have that. $\mathrm{FV}$ organization is quite informal and there is no formal accounting or book keeping. Even inventory control is elementary.

\section{MARKETING}

FV do not have a mission or a vision as such. They survive day to day. They do not have company objectives laid out before them to achieve in short or long term. They are more occupied with day to day affairs. When probed deeply Faisal revealed that if they take all overheads into account they may not be breaking even if his salary is included in overheads. Then why should he be doing what he is doing. He thinks it is the satisfaction of having his own business. And he enjoys the independence. He is not answerable to anyone and can do things his way at his own pace and how and when he likes.

To the question as to what is their business FV do not have a clear answer. They succumb to the often used product categories approach in defining their business rather than need based. If they would define their business in terms of needs categories they satisfy, they would have much more flexibility in providing solutions for their customers. It would suggest new ideas for product development, market development and even diversification to satisfy customers. In discussion with Faisal it came out that expansion can be done either with product development in related categories or in market development for the same product. And as it is a lifestyle 
product there may be extensions into other related life style products, e.g., supplementary use products like hand bags, shoes, etc. or even in cosmetics and artificial jewellery. For this FV has to understand its customers and know as to what additional items they buy to satisfy their lifestyle related needs.

So far typical consumer has been the youngish female from 25 to 40 years of age living in Defense, Clifton, or PECHS area with an income of Rs. 100,000 per month or above. Most of them have been to English medium schools and are rather westernized and watch local and foreign TV channels and read local fashion magazines.

\section{THE 4 PS PRODUCT}

FV do have a rather vague idea of their product but the same is not defined in terms of the customer. They are not clear as to the need category they cater to. And whether there can be alternative means to satisfy this category of needs. Their product keeps changing with time in terms of style, fabric and occasion but it remains within the broader confines of women's apparel. Do they make conscious innovations? I think to an extent yes they do. But there is a lot of scope to think out of the box. To think of new ways to satisfy women's need of expression. There could all types of ideas from being a middle man for foreign manufacturers to being a middle man for local exporters abroad. And he can think in terms of other products. To think in terms of new locations, new geographical areas, men's market, children's market, and so on. Also there are possibilities in terms of increased usage of the same product to introducing more styles and designs of the same product. Also one can think in terms of market development towards women's executive wear.

Recently FV has acquired an order from Air Blue to stitch uniforms for air hostesses. This is a local airline flying local routes in Pakistan. With this order Fv has moved into organizational market. This will help create economy of scale, add to its image as a serious contender in the local market and help in its diversification strategy. This may be an exciting turn of events for FV. This may generate a new market helping it to sustain itself and retain the employees it has even in bad times. However this is not the usual business. A uniform is the exact anti thesis of a fashion garment. It is a type of mass production product. If the business can be expanded to other airlines it may be a viable alternative to or addition to the fashion products which are by nature fickle and ever changing. But this offers great opportunity for them to enjoy economy of scale and thus have a more free hand in the kind of business they enjoy doing. This new reference needs to be exploited fully in terms of promotion and made a stepping stone into other such business. 


\section{PRICING}

Pricing is done rather smartly by FV. They do not sell on prices. This is in spite of the fact that even the most moneyed women always haggle for the discount. FV has distanced themselves from the run-of-the mill tailoring outfit which caters to the middle class at less than half the price. They have happily been able to distinguish themselves from such outlets. This indicates they must be offering something extra in order for them to continue getting customers for tailoring. In fact now custommade merchandise sells more than the ready made designs FV offer off the shelf. When asked which pricing methods are used to price their products FV said they mostly used cost plus pricing.

\section{PROMOTION}

FV has done better than most small firms seem to do in Pakistan in terms of promotion. They seem to understand how to stretch their budget to their advantage. This is accomplished through various low cost promotional techniques. They have an effective give-away scheme including small items which keep their name in front of customers. They also use hoardings effectively. Their presence on media in terms of interview of Faisal is also a great help. They have used exhibitions also with limited success. One of the tools still not used is the direct mail. For this they need an effective data bank of customers and prospects which they agreed to organize. Air Blue uniform stitching business is a feather in their cap and can be a good reference if used intelligently. This can give them an edge and entry into more organizational business.

\section{PLACEMENT}

FV being a small company and a retail business has fixed their primary trading area as Defense, Clifton and PECHS areas. These are the topmost residential areas in Karachi. But secondary trading area for FV is other areas of Karachi including Gulshane Iqbal, Nazimabad and other middle class areas. Their tertiary trading area is the whole of Pakistan. For now FV are concentrating mostly on the primary trading area. Their distribution is limited to the posh areas of Karachi the center of which for this business is the Zamzama shopping center. For organizational customers location is not a factor. They can reach wherever they have to in order to get their type of product. FV do get some business from other cities and the product is delivered through the mail. This is a good strategy. There are some clients even in as far as Dubai. 


\section{MARKETING ORIENTATION}

FV is marketing oriented to only an extent. This means they do consider the market in introduction and sustenance of products. But they are not doing formal market research. Most of the knowledge of market is based on interaction with customers. This is a limiting factor as the untapped customers out there cannot be approached. There is also no built in system to gauge customer satisfaction. As we know $90 \%$ of unsatisfied customers never come back to report. They need to be sought out. And this requires making it easy for them to give their feedback. This can be done through a short Performa to be filled out by customers after purchase or it can be done in other ways. A small gift can be presented for this courtesy.

\section{MARKETING PLANNING}

In FV there is no marketing planning. All planning is in the head of the owner. When planning is not done many things are hidden and weaknesses may not be known. Planning, its implementation, and monitoring, forces managers to think, and these open many avenues for improvement. In crisis, planning may be especially useful. Sometime FV have orders to meet for which they may need extra manpower which they may hire from outside on a part time basis, or bring in ex employees. This is example of a mini crisis which may be overcome through crisis planning. Also there are occasions for opportunistic planning. This may be the case when there is opportunity to gain market share if product can be made available on a short notice. In any case a small business has to be adept at the art of planning for the sake of its own success. The plan also clarifies the purpose of business, the target customer, benefits of product, positioning, marketing strategy and tactics, and marketing budgets.

\section{BRANDING}

In the area of branding FV has had some success. They have actively made efforts to create their brand, build its image and try to capture share of mind with the target market. FV has however not connected the brand with the product. The product is produced under 'Mian's Fashions'. Thus there are two entities to deal with. Fashion Vibes and Mian's Fashions. Under Mian's Fashions they have Mian's Nightwear and Mian's Kurtis, etc. This is good marketing. The name Mian is connected with the name of Mian the owner and designer. This is the tradition in the world of fashions globally and in Pakistan. There are many examples locally including Nadia Mistry and Nabila where fashion related products are being marketed under the name of the designer/owner. We see the same trend abroad, e.g. Estee Lauder, Versace and so on. FV has promoted the brand with a consistent branding policy. This includes promotion of the brand through hoardings, ads in magazines, fashion shows; give aways, point of sale advertising, TV interviews, and TV slides in local film channels 
which show Indian movies. Thus it may be said brand 'Mian's Fashions' has fairly wide recognition among target market. But FV has not done a survey to measure brand recognition. This is one thing that may help them. And it should include questions regarding the perception of the brand and its image. Much more needs to be done to flood the market with the brand name. But then there should be capacity within FV to meet increased demand thus created.

\section{NETWORKING}

FV has a fairly broad networking. This is accomplished by Faisal through club memberships, including activity in the Rotary Club; vast personal friendship network, based on Faisal's own and his wife's friends. They are quite particular to use any and all opportunities to meet people and to be on the good side of significant people who can help in business and personal life. Still the networking can be more organized. And it needs to be systematized. They need a data base of all the clients and need to send letters to them off and on regarding new arrivals, new fashion trends, and any other important developments or news. In this business networking also needs to be done with suppliers, tailors, fashion designers, fashion scene abroad, exhibitions and events, advertising agencies, TV channels, media, graphic designers, exporters, and agents abroad. Fashion schools in Pakistan need to be targeted to attract talent and students to undertake new projects and create new designs. Also to be targeted include prospective organizational buyers, airlines, hotels, elite clubs, and other opinion leaders.

\section{IS FV SUCCESSFUL}

How are we to judge success of small business? Literature suggests success is not one-dimensional. It is measured by financial, marketing and owner's success criteria. Financially, FV is marginally successful. If the overheads do not cover the owner's salary, we have to also take into account the other factors that determine financial success. This includes property appreciation. Property in Pakistan is the best investment. It has yielded unprecedented returns. Thus the property used for the outlet has in all probability given more than the rate on any other investment. And this cannot be taken out of the calculations. Similarly there is sufficient brand equity now in the MF name to have a goodwill value with its many clients.

Owner's satisfaction is the foremost criterion especially in a lifestyle business like this one. The quality of life afforded to the owner and family in having the peace of mind, independence, proximity of home to the work premises and the joy of creation and contributing to the fashion scene all need to be assigned high value. Thus FV is a successful enterprise. And above all it is indeed making a very useful contribution to the economy by providing employment to 20 persons and thus a source of livelihood 
to about 100 or more persons including the dependents of workers. Value of such small industrial units cannot be undermined.

\begin{abstract}
ANALYSIS AND RESULT
FV is doing marketing in an entrepreneurial style. It is based on owner's judgment, his risk taking instinct and his innovation. First generation entrepreneurs typically follow this style. There is no formal marketing. Using what he learned in the MBA program Faisal tried to do marketing as he saw fit. This included in the beginning some ads in the local fashion magazines. Then later on he went for hoardings. Small gift items were introduced and a calendar with FV logo and a nice depiction of its activities on the back was given away by boys hired to do so to cars on the main highway. Later this changed to a small and golden colored telephone directory with magnetic shutting mechanism.
\end{abstract}

We see that being educated in business did make a difference in this case as the owner immediately moved to some kind of promotion and invested in it. Comparing this with Essa where the owner is a medical doctor we see that Essa knew they wanted to do something yet they did not hit the nail on the head. Thus we can conclude that education of the owner manager in the field of business can be one important element towards some kind of marketing activity though it may not be systematic or scientifically designed as in case of big companies. In FV case we see some minimum elements of various efforts in bits and pieces and attempts at marketing with moderate success. Thus there are two things: education of the owner and then business education of the owner which seem to make a difference.

Thus far we see that formal marketing planning is not there in any case studied. Marketing orientation is also not there. It gets introduced to an extent as the business starts to grow and as competitive pressure is felt. This is indicated by owner's outward interest as to what is happening in the market and in which direction it is moving. No one so far seems to have any idea of a vision or mission or of long term objectives. They seem to be occupied with the day to day survival in the beginning which takes the toll on their energies. And thinking of marketing only comes later when they have some peace of mind and look outwards to see what more can be done. Thus we see in the introductory phase when marketing is needed most it is not coming. It may start to appear like in case of Ping when the company looks for growth and has passed its initial phase of start up. We see in FV that the entrepreneur has shown innovation in introduction of night wear at a time when no one else was doing it in the country. Thus innovation is very important in the lifestyle business. This aspect of entrepreneurship is especially applicable to products where the buying motive is to be different from others and not to satisfy a practical need e.g. buying a computer software or hardware. 


\section{CONCLUSION}

SMEs studied so far are not doing marketing planning. They are marketing oriented to only an extent. They resort to marketing orientation when they are past the pressures of start up phase. Marketing orientation is not formalized. There is no formal marketing research. Branding is known and initiated by some depending on the type of business. However networking is the mainstay of most of the SMEs. They do have extensive recourse to family and friends for getting orders. Networking among competitors is also a remarkable fact of SMEs. The extent of networking and cooperation among competitors is impressive. There is evidence of comradeship and support for each other. Educated owner/managers act in different ways than uneducated one. They understand the importance of marketing even if they don't practice it. And they think that they will use marketing at some future date if not now. They also see the value of investment in marketing.

Among tools used in marketing in Pakistan, direct mail appears to be useful. This can be a reality in face of appearance of email lists in the market which are very cost effective. A list of 100,000 names with a price of Rs. 5,000 is extremely cheap compared to the price of a similar list being at least 50 times higher in Canada which the writer has experience of using.

Internet has not been used much by SMEs yet. It is a great opportunity for some types of business dealing with products that are targeting educated people who have access to computers. I think this is a vast, yet untapped resource.

\section{CASE NO. 4: MPL (Mehdi Pak Ltd.) (Small enterprise)}

\section{HISTORY}

MPL is a sole proprietorship owned by Mr. Baqar Mehdi. Baqar is a Master's degree holder from Karachi University. He has never worked for anyone and is proud to have been an entrepreneur from the first day. The set up was established with the support of his family all of whom later migrated to USA leaving him behind. He is not in favor of living abroad as he is quite happy in Pakistan.

MPL was established in 1985 in the same office in the most centrally located Metropole Hotel in Karachi, one of the oldest buildings which now houses mostly offices in addition to an old and dilapidated hotel. MPL has three divisions: Aviation Consultancy (includes all travel related business), Training Division (for training personnel in aviation and ticketing), Cotton Division (an online cotton exchange house). It is an interesting set up contrived by Baqar. This shows a creative use of manpower and resources to do more than one task thereby creating economy of 
scale. Except cotton, the other two businesses are related and provide support to each other. This synergy helps profitability and growth and also keeps the name of the enterprise in minds of prospects.

\section{WHAT MPL DO?}

Main activities of the travel business of MPL are air ticketing, tour operation, umra and hajj arrangements. The travel business is nicely tied in with the training business. Modus operandi of MPL is simple. They train young people in ticketing and aviation through two courses, one a three year diploma and the other a short certificate course of three months. These graduates usually are able to place themselves in the aviation industry rather easily. They are hired by airlines and travel agencies. In this they are helped by Baqar. Baqar later maintains a constant liaison with these graduates. $\mathrm{He}$ keeps them as 'part time consultants' with the possibility of earning money by referral of clients to him. Thus he is able to keep a constant flowing stream of travel related customers flowing into the agency office. He charges a reasonable fee of Rs. 40,000 for a three year diploma which is awarded by IATA and Rs. 6,000 for certificate course. He started the training program as he likes this activity and he likes to give something back to the country. There are about 100 students enrolled. Each has three classes daily.

Baqar established another interesting business on the side i.e. Cotton exchange. He realized about fifteen years ago that various small cotton traders wanting to trade their own cotton found it very hard to reach prospective buyers profitably. $\mathrm{He}$ thought why not create an online business to bring the buyers and sellers to their mutual advantage. Thus he created an E-COTTON EXCHANGE with the website www.e-cottonexchange.com. This is a platform for exchange of cotton worldwide joining in with other cotton exchange websites. Before this he was already a member of the cotton exchange in Karachi.

\section{MACROENVIRONMENT}

\section{COMPETITIVE}

Airline and travel industry in Pakistan is fairly well established. There are 120 IATA certified and 300 non IATA agencies in Pakistan. There is a lot of competition in the industry. Some do resort to price cutting but the IATA agencies usually do not. Competition is usually in terms of networking, extra services, and speed and reliability of operations. It needs substantial investment to have IATA certification. And this certification can also be sold to other parties. Non IATA agencies buy tickets from IATA agencies. Usually a commission of about 8 to $9 \%$ is charged on a foreign ticket and $5 \%$ on local ones. Almost 50 new agencies arrive each year among whom at least $5 \%$ fail according to Baqar. Most small agencies have 
financial problems as they have to carry inventory of tickets which is very costly. IATA license is now sold in the market for 4 million rupees.

Five big agencies generate $50 \%$ of total revenue in the airline business. These include: American Express, Gerry's Travels, Princely Travels, Polani, and Bukhari. The rest of the business is shared among the rest of the hundreds of agencies.

\section{SOCIAL AND CULTURAL}

Air travel is now very common in Pakistan. Many of those who used to travel very little or travel by rail have now moved to air travel. There are 5 airlines in Pakistan all competing with each other mostly on price. Travel agency business is more than just air booking. Most people who travel by air usually go through travel agency. It is a symbol of prestige in Pakistan to travel by air and now even the middle class all travel by air. Railway travel is not pleasant as the railway service is not good.

\section{ECONOMIC}

With increase in purchasing power of the common man in general, there is lot of demand for air travel for local and foreign destinations. Thus was seen the emergence of private airlines in addition to the national career PIA. With growth of air travel there is also increased demand for travel agencies.

\section{MICROENVIRONMENT}

MPL has 20 full time employees. They are assisted by what they call part time consultants who are graduates of the company and are out in the field and are constantly referring clients to them. MPL has a well established facility in their office with class rooms with all gadgets and seating arrangements to accommodate students enrolled in their various courses. They have hired senior manpower including retired personnel from PIA and travel agencies to offer class room instruction. They have enough personal computers for teaching purpose and for air travel business. 


\section{MARKETING}

\section{PS PRODUCT}

When asked what was the main product of MPL I was told it is the travel and travel related services which a traveler may need. Enlisting the same Baqar told me it could include the following:

Reliable seat reservation

Connections and stop overs

Cheapest flight search with appropriate timings

Meals

Special seat reservation including bulk head, etc

Special meal requirements including Muslim meal

Hotel bookings

Travel insurance

Tour arrangements within and outside cities

Rail bookings

Car bookings

Airport escort service

Foreign exchange arrangements

Wheel chair and special handling

Infant cots

And many others

Thus the concept of product in this case for MPL is the complete one window operation for all your needs. This is usually better than what airlines are directly able to supply to their customers. So what is the concept of product to the customer? It is the easy and quick reliable availability of all of these benefits for a good price. From consumer behavior point of view it is the ease and peace of mind that you are in good hands. And it is the reliable and enjoyable travel which is hassle free. For business and pleasure travel there is significant difference in the perception of the travel service. And their needs are different too. MPL has to understand and cater to both these markets. The break up of the two segments is individual $60 \%$, organizational $40 \%$.

\section{PRICE}

In this business price is more or less fixed and to give discount is against IATA regulations. Thus there is no price competition among the reputable agencies. But the non IATA agencies do involve in discounts and make that as an attraction for their customers. This is a poor strategy. Discounts lead to more discounts till all are losers. This is also an acceptance of the fact that price should not be the selling factor for such a business. MPL does not compete on price but some non IATA agencies do 
and this is a known fact. But this trend makes competition unhealthy. It is the endeavor of the established quality agencies to shift the trend away from the price while the smaller non IATA agencies usually work in the opposite direction. ।

\section{PROMOTION}

MPL does the following:

Newspaper ads in Holiday Travel Magazines

Personal selling through part time consultants who are ex students of the MPL (generating $20 \%$ of total business)

Networking among the business circle (10 to $15 \%)$

Website $(5 \%)$

E-marketing (5\%)

Other non IATA agencies

Word of mouth

Special hajj and umra programs promotions

Various special offers to companies and their personnel

Financial deals to companies and individuals for 45 days credit

\section{DISTRIBUTION}

MPL tries to increase its distribution through its network of part time consultants and through e-marketing. Also being an accredited agency its distribution is as wide as that of the agencies dealing with it. Nevertheless being a single outlet agency it has limits to its presence and cannot do business in the whole of Pakistan. Its primary trading area remains the posh areas of Karachi for individual customers. And for the organizational customers its primary trading area remains the whole of Karachi and companies which are doing their purchases in Karachi. Like in all retail business, location remains critical. Though location of MPL is Metropole Hotel which is right in the midst of Karachi and in the thick of all routes that link to the most important areas of Karachi, the exact location of it is on the second floor which is not visible from the main road. This means that they cannot get the traffic walking off the main road. Also those that are indifferent to any agency will for convenience walk into the one that comes easy. Thus MPL has this disadvantage. Only people who are actively looking for it are likely to climb two floors to reach it.

\section{MARKETING ORIENTATION}

To a great extent MPL is marketing oriented. It constantly adjusts its offer in line with its customers' choice. In this kind of business it is easier to do. But there is no formal marketing research to find out what the prospective customer may want. This means playing by feel. Thus their intelligence is limited to the customers with whom they have interaction and not with those they do not see. 


\section{MARKETING PLANNING}

They do have written marketing plan which could not be seen. It outlines their objectives for the next year. And it gives the profit projections for all types of customers. The plan is loosely implemented.

\section{BRANDING}

MPL is careful about its brand name which it projects actively in the market. It wants to be perceived as a company of repute giving reliable service to its clients and having a substantial client base. They are projecting this brand through use of various tools outlined above. And these are pushed through their literature.

\section{NETWORKING}

As observed with all the SMEs in Pakistan networking is the core marketing activity. It is the case here too. Baqar is very good and effective net worker. He has networked himself with all stakeholders not only in the aviation industry but also in the cotton exchange industry. He works hard many times till late in the night. He is a good example of an intelligent and knowledgeable entrepreneur who knows his business and also serves as role model for others.

\section{PERSONAL SELLING}

This is the promotion activity which is most often utilized in MPL. They make it a point to present themselves to their clients in several ways. They have a good sales approach in terms of understanding customers' psychology. Baqar thinks knowing customers' psychology is important and he adjusts his sales presentation to suit the prospect. He says it is important to know what the state of mind of the prospect is and emphasize that to him. For example if he is price conscious then it is important to stress lower prices, and if he is interested in being pampered during his travels the same be made available to him. In spite of this he thinks there should be no lies spoken to the prospect, and no misinterpretations made. Some clients are sensitive and need respect more than others. The seller should give him respect. He even goes to the extent of emphasizing the importance of a good hand shake and he says sale starts right from the time of the first hand shake.

\section{FACTORS FOR SUCCESS AS ENUNCIATED BY BAQAR}

According to Baqar the most important factor for success for entrepreneur is devotion to what he does. He must have an objective in mind. Regarding marketing success he said one must have marketing ability. He also thinks environment plays 
an important role in it. There must be demand for the product you enter in. And there should be supportive rules, regulations and government policy. Then he also suggested role of honesty of thought. That is one must be honest in ones thinking and be genuine business man out to serve the community. He thinks one must be result oriented.

\title{
ANALYSIS AND LEARNING
}

In this case we learnt that marketing success depends on networking and making a sort of web in the market like Baqar did through his network of consultants. He also made full utilization of his capacities by adding the business of training to his travel business. And in this he was guided by his natural aptitudes. Thus we find another new variable in this situation that one is likely to succeed more in the type of activity which one likes to do. Baqar liked to teach and he liked the feeling of giving back to the community from which he was earning his livelihood. Thus he was a supporter of corporate social responsibility and community involvement. He went to the extent of getting his institute recognized by IATA as an institute authorized to give diploma on behalf of IATA. Thus he did many things thorough this single activity. He not only created an edge in his business for himself (which is again a new variable worth exploring) but also created new advocates in the market for him who not only did business on his behalf but also through their good work created an image for MPL. And name of MPL became known for authority on the business of aviation. Thus he was able to compete to an extent with the giants of the industry who were financially much stronger by creating this competitive edge. He also diversified his business and created the e cotton exchange. Thus the same office premises internet facilities and computers which would lie idle at night were used in this new business. This gave him a much greater utilization of his resources. Thus we see here creativity is another factor that goes to the credit of Baqar and thus to MPL. This also needs a study. Small businesses which use creativity are able to succeed much more in competitive markets and are also likely to survive in adverse circumstances by having something to fall back upon when things are not going well in their main business.

\section{NEW VARIABLES FOUND}

\author{
Marketing ability \\ Community involvement \\ Creativity \\ Marketing synergies \\ Product development \\ Diversification
}

(To Be Continued) 


\section{REFERENCES}

Aldrich, H., and E. Auster (1986). Even Dwarfs Started Small: Liabilities of Size and Their Strategic Implications, In Research in Organizational Behavior, Vol. 8 Ed. B.M. Staw and L. L. Cummings. Greenwich, Conn.: JAI Press, 165-198.

Amit, R., Schoemaker, P. (1993). Strategic assets and organizational rent. Strategic Management Journal, Vol. 14 No.1, pp.33-46.

Appiah-Adu, Kwaku (1998). Marketing activities and business performance: evidence from foreign and domestic manufacturing firms in a liberalized developing economy. Marketing Intelligence \& Planning, 16/7 1988 pp 436-442.

Audretsch, David B. (1990). The Economic Role of Small and Medium-sized Enterprises: The United States. Paper prepared for the June 11-12, World Bank Workshop on Small and Medium Enterprises.

Barney, J.B. (1986). Strategic factor markets: expectations, luck and business strategy. Management Science, Vol. 32 No.10, pp.1231-41.

Barney, J.B. (1991). Firm resources and sustained competitive advantage. Journal of Management, Vol. 17 No.1, pp.99-120.

Barringer, B. R., F. F. Jones and D. O. Neubaum (2005). Journal of Business Venturing 20 (2005), pp. 663-687.

Beam, H.H. and Carey, T. A. (1989). Could you succeed in small business? Business Horizons, Vol. 32 No. 5, September/October, pp. 65-9.

Benedetto, C. Anthony Di, Song, M. (2003). The relationship between strategic type and firm capabilities in Chinese firms. International Marketing Review, Vol. 20, No. 5 .

Berry, Albert, and Dipak Mazumdar (1991). Small-scale Industry in East and Southeast Asia: A Review of the Literature and Issues. Asian Pacific Economic Literature 5: 2, 35-67.

Braggs, S. M. (1999). Managing Explosive Corporate Growth. New York: Wiley.

Brickau, R. (1994). Responding to the Single Market: A Comparative Study of UK and German Food Firms. Unpublished Ph.D. Dissertation. University of Plymouth, Plymouth, UK. 
Bruno, A.V. and Leidecker, J.K. (1988). Causes of new venture failure: 1960s vs. 1980s. Business Horizons, Vol. 31 No. 6, November/December, pp. 34-49.

Burns, P. (1994). Keynote address. Proceedings of the $17^{\text {th }}$ ISBA Sheffield Conference, ISBA, Leeds, UK.

Capron, L., Hulland, J. (1999). Redeployment of brands, sales forces and general marketing management expertise following horizontal acquisitions: a resource-based view. Journal of Marketing, Vol. 63 No. April, pp.41-54.

Carland, J.W., F. Hoy, W. R. Boulton, and J. C. Carland (1984). Differentiating Entrepreneurs from Small Business Owners: A Conceptualization. Academy of Management Review 9(2), 354-359.

Carson, D. (1985). The evolution of marketing is small firms. European Journal of Marketing, Volume 19, No. 5, pp 7-16.

Carson, D. (1990). Some explanatory models for assessing small firms' marketing performance (a qualitative approach). European Journal of Marketing, Vol. 24 No. 11 , pp. 5-51.

Carson, D. (1993). A philosophy for marketing education in small firms. Journal of Marketing Management, Vol. 19 No. 2, pp. 189-204.

Chaston, I. and Terry Mangles (1997). Core capabilities as predictors of growth potential is small manufacturing firms. Journal of small business management, Jan. Chell, E., J.Haworth, and S. Bearley. (1991). The Entrepreneurial Personality: Concepts, Cases and Categories, Routledge, London.

Chen, J.S. (1993). Networking and Life Structure: Social and Economic Analysis of Small and Medium Enterprises in Taiwan. Taipei: Lian Geing Publishing Co. (in Chinese).

Coopers \& Lybrand (1994). Made in the UK: The Middle Market Survey. London: Coopers \& Lybrand.

Coulter, M. (2002). Strategic Management in Action, 2nd ed., Prentice-Hall, Englewood Cliffs, NJ.

Davis, C.D, Hills, G.E, LaForge, R.W. (1985). The marketing/small enterprise paradox. International Small Business Journal, Vol. 3 pp.31-42.

Deeds, D. L.., Hill, C.W.L. (1996). Strategic alliances and the rate of new product development: an empirical study of entrepreneurial bio technology firms. Journal of Business Venturing 11 (1), 41-55. 
Dierickx, I., Cool, K. (1989). Asset stock accumulation and sustainability of competitive advantage, Management Science, Vol. 35 pp.1504-11.

Doorley, T.L., Donovan, J.M. (1999). Value creating growth. San Francisco: JosseyBass.

Doyle, Peter \& Graham Hooley. . (1992). Strategic orientation and corporate performance. International Journal of Research in Marketing. 9(1): 59-73.

Drucker, P. (1986). Innovation and Entrepreneurship, Heinemann, London.

Ellis, Paul D. (2005). Marketing orientation and marketing practice in a developing economy. European Journal of Marketing, Vol. 39, No. 5/6.

Ennew, C. T. and M. R. Binks. (1998). Marketing and Entrepreneurship: some contextual issues, in Hubert, B., Day, J. and Shaw, E. (Eds), Proceedings of the Academy of Marketing Symposia on the Marketing and Entrepreneurship Interface 1996-1998, Nene University College, Northampton.

Evans, S.J. (1991). Strategic flexibility for high technology maneuvers: a conceptual framework. Journal of Management Studies, Vol. 28 No. January, pp.69-89.

Fleisher, C.S., Bensoussan, B.E. (2003). Strategic and Competitive Analysis: Methods and Techniques for Analyzing Business Competition, Prentice-Hall, Englewood Cliffs, NJ.

Giamartino, Gary (1991). Will Small Business be the Answer for Developing Economies? Journal of Small Business Management. 29(1) pp. 91 -93.

Grant, R.M. (2002). Contemporary Strategic Analysis, 4th ed., Blackwell, Oxford,

Haber, Siegal and Reichel, Arie (2003). The cumulative nature of the entrepreneurial process: The contribution of human capital, planning and environment resources to small venture performance. Journal of Business Venturing 22 (2007) 119-145.

Henderson, R., Cockburn, I. (1994), Measuring competence? Exploring firm effects in pharmaceutical research, Strategic Management Journal, Vol. 15 No.S2, pp.6384.

Hankinson Alan, (2000). The key factors in the profiles of small firm ownermanagers that influence business performance. The South Coast Small Firms Survey, 1997-2000, Industrial and Commercial Training. Vol. 32, No. 3, pp. 94- 98.

Hannan (1987). Fast Growth Strategies. New York: McGraw Hill. 
Hansen, E. L. (1995). Entrepreneurial networks and new organizational growth. Entrepreneurial theory and practice 19 (4), 7-19.

Harrison, J., Taylor, B. (197). Supergrowth companies. Oxford: Reed Educational and Professional Publishing.

Heunks, F. (1998). Innovation, creativity and success. Small Business Economics 10 (3), 263-272.

Hills, G. E. (1987). Marketing and entrepreneurship research issues: scholarly justification, in Hills, G. E. (Eds), Research at the Marketing/Entrepreneurship Interface. The university of Illinois at Chicago, IL, pp. 3-15.

Hisrich, R.D (1988). The entrepreneur in N. Ireland: characteristics, problems and recommendations for the future. Journal of Small Business Management, Vol. 26, pp.32-9.

Hisrich, R.D., and M. P. Peters (1992). Entrepreneurship: Starting, Developing, and Managing a New Enterprise. Boston, Mass.: Irwin.

Hogarth-Scott, S., Watson, K. and Wilson, N. (1996). Do small business have to practice marketing to survive and grow? Marketing Intelligence \& Planning, 14/1, pp. 6-18.

Hooley, G. J. and Jobber, D. (1986). Five common factors in top performing industrial firms", Industrial Marketing Management, Vol. 15 No. 2, pp. 89-96.

Jaworski, Bernard J. \& Ajay K. Kohli (1993). Market orientation:

Antecedents and consequences. Journal of Marketing. 57(3): 53-70.

Johnstone, H, Kirby, D. (1992). Small firms and the recovery of the economic environment in Britain. Enterprising in Partnership with the Environment, Proceedings of International Council for Small Business, Toronto, pp.669.

Kaplan, R. S., Norton, D. P. (1996). The Balanced Scorecard: Translating Strategy into Action, Harvard Business School Press, Boston, MA.

Kazmil, Azhar \& Farooquie, Jamal. Awareness and Management of Productivity in Small Scale Enterprises in the Indian State of Uttar Pradesh. Journal of Enterprising Culture 8(3) Sep 2000: pp. 255-270.

Kenny, B. and Dyson, K. (1989). Marketing in Small Business. Routledge, London. 
Kohli, A. J. and Jaworski, B. (1990). Market orientation: The construct, research propositions, and managerial implications. Journal of Marketing 54 (April), 1-18.

LaFuente, A, Salas, V. (1989). Types of entrepreneurs and firms: the case of new Spanish firms. Strategic Management Journal, Vol. 10 pp.17-30.

Leigh, R., North, D. and Smallbone, D. (1990). Growth in small and medium sized manufacturing enterprises during the 1980s. Paper presented to the $13^{\text {th }}$ National Small Firms' Policy and Research Conference, Harrogate.

Lin, C. Y. (1998). Success Factors of Small- and Medium-Sized Enterprises in Taiwan: An Analysis of Cases. Journal of Small Business Management, Oct 98, Vol. 36 Issue 4, p. 43-56.

Lin, Y. Y. (1996). The Training and Development Practices in Taiwan: A Comparative Study of Taiwanese, USA, and Japanese Firms in Taiwan. Asia Pacific Journal of Human Resources 34(1), 45-62.

Lussier, R.N. and Pfeifer, S. (2001). A Crossnational Prediction Model for Business Success. Journal of Small Business Management 2001 39(3), pp. 228-239.

Masurel, Enno, Smit, Hidde, P. (2000). The planning behavior of small firms in Central Vietnam. Journal of Small Business Management, 00472778, April 2000 Vol. 38 , Issue 2 .

Medium Term Development Framework (MTDF), 2005-2010, Planning Division, Government of Pakistan.

Montague-Pollock, M. (1991). All the Right Connections. Asian Business, January, 20-24.

Narver, John C. \& Stanley F. Slater. 1990. The effect of market orientation on business profitability. Journal of Marketing. 54(4): 20-35.

Oakley, R. (1991). Innovation and the management of marketing in high technology small firms. Journal of Marketing Management, Vol. 7 No. 4, pp. 343-56.

O'Regan, N. and Ghobadian, E. (2004). The importance of capabilities for strategic direction and performance. Management Decision Volume 42 Number 22004 pp. 292-313

Pakistan Statistical Yearbook (2006). Statistics Division, Ministry of Economic Affairs and Statistics, Government of Pakistan. 
Patten, D. (1989). Successful Marketing for the Small Business. Routledge, London.

Pelham, A. M. and D. T. Wilson. (1996). A longitudinal study of the impact of market structure, firm structure, strategy, and market orientation culture on dimensions of small-firm performance. Journal of the academy of marketing science 24(1), 27-43.

Peteraf, M.A. (1993. The cornerstones of competitive advantage: a resource-based view. Strategic Management Journal, Vol. 14 No.3, pp.179-91.

Poutziouris, P. (2003). The strategic orientation of owner managers of small ventures: evidence from the UK small business economy. International Journal of Entrepreneurial Behavior \& Research Volume 9 Number 5 pp. 185-214.

Rana, A., Khan, J., Asad, A. and Mian, S. A. (2003). The SME Pulse: An exploratory Study of the Performance of SME'S in Pakistan and the Characteristics of Successful Firms. Small and Medium Enterprise Center, Lahore University of Management Sciences.

Risseeuw, RA., and E. Masurel (1994). The Role of Planning in Small Firms: Empirical Evidence from a Service Industry. Small Business Economics 6, 313-322.

Reynolds, P. (1987). : New Firms: Societal Contribution Versus Potential," Journal of Business Venturing 3, 231-246.

Rich, J. T. (1999). The growth imperative. Journal of Business Strategy 20 (2), 2731 .

Robert N. Lussier and Sanja Pfeifer (2000). Journal of Small Business Management 39(3), pp. 228-239.

Roomi, M. A. and Hussain, S. T. (1998). SMEs in Pakistan: A survey of their problems and prospects. Small and Medium Enterprise Center, Lahore University of Management Sciences.

Roper, S. (1997). Product innovation and small business growth: a comparison of the strategies of German, UK, and Irish companies. Small Business Economics 9(6), 523-537.

Rumelt, R.P. (1991). How much does industry matter? Strategic Management Journal, Vol. 12 No.3, pp.167-85.

Salleh, A.H.M. (1995). Marketing Management Challenges of S.M.E. Bumiputera Enterprises in Malaysia. An International Conference Nov 24-26, 1995, Bandar Seri Begawan. 
Sapienza, H., Grimm, C. (1997). Founder characteristics, start-up process and strategy/structure variables as predictors of shortline railroad performance. Entrepreneurship: Theory and Practice 22 (1), 5-24.

Simon, H. (1996). Hidden Champions. Boston, Mass.: Harvard Business School Press.

Siu, Wai-sum (2000). Marketing and company performance of Chinese small firms in Hong Kong. Marketing Intelligence \& Planning, 18/5 (2000), pp. 292-307.

Singer, B. (1995). Contours of development. Journal of Business Venturing 10 (4), 303-329.

Shane, S. (1993). "Cultural Influences on National Rates of Innovation," Journal of Business Venturing 8, 59-73.

Stanworth, J. and Gray, C. (1991). Bolton 20 Years On: The Small Firm in the 1990s, Paul Chapman, London.

Stokes, D. (2000). Entrepreneurial marketing: a conceptualization from qualitative research. Qualitative Market Research: An International Journal Volume 3 Number 1, 2000 pp. 47-54.

Stokes, D.R., Fitchew, S., Blackburn, R. (1997). Small Business Research Centre, Kingston University, Kingston-upon-Thames, Marketing in small firms: a conceptual approach. Report to the Royal Mail.

Szarka, Joseph (1990). Networking and Small Firms. International Small Business Journal 2 (January to March).

Teece, D.J., Pisano, G., Shuen, A. (1997). Dynamic capabilities and strategic management. Strategic Management Journal, Vol. 18 pp.509-33.

Teece, D. J. (1998). Technological change and the nature of the firm, in Dosi, G. (Eds), Technological Change and Economic Theory, Francis Pinter, London.

Tiessen, J.H. (1997).Individualism, Collectivism, and Entrepreneurship: A Framework for International Comparative Research. Journal of Business Venturing $12,367-384$.

Tradenz (1990). Export Manufacturing-Framework for Success. Wellington, New Zealand: New Zealand Trade Development Board. 
Urata, Shujiro, and Hiroki Kawai (1998). Technological Progress by Small and Medium Enterprises in Japan. Paper prepared for the June 11-12, World Bank Workshop on Small and Medium Enterprises.

Watson, W., Steward, W., BarNir, A. (2003). The effects of human capital, organizational demography, and interpersonal processes on venture partner perceptions of firm profit and growth. Journal of Business Venturing 18 (2), 145-164.

Weinrauch, J.D., Man, K., Robinson, P.A., Pharr, J. (1991). Dealing with limited financial resources: a marketing challenge for small business. Journal of Small Business Management, Vol. 29 No.4, pp.4-54.

Wernerfelt, B. (1984). A resource-based view of the firm. Strategic Management Journal, Volume 5, issue 2, April-June

Wijewardena, H., A. De Zoysa, T. Fonseka and B. Perera (2004). The Impact of Planning and Control Sophistication on Performance of Small and Medium-Sized Enterprises: Evidence from Sri Lanka. Journal of Small Business Management 2004 42(2), pp. 209-217.

Wilson, N., Hogarth-Scott, S. and Watson, K. (1994). Winners and losers: a study of the performance and survival of TEC supported new start businesses in West Yorkshire. Paper presented to the Entrepreneurship Research Conference, Babson College and Kauffman Foundation, Boston, MA.

Yusuf, A. (1995). Critical Success Factors for Small Business: Perceptions of South Pacific Entrepreneurs. Journal of Small Business Management 33 (2), pp 68-74.

Zontanos, G. and A.R. Anderson (2004). Relationships, marketing and small business: an exploration of links in theory and practice. Qualitative Market Research: An International Journal Volume 7 Number 3 pp. 228-236. 
https://ir.iba.edu.pk/businessreview/vol3/iss2/11

DOI: https://doi.org/10.54784/1990-6587.1157

Business Review - Volume 3 Number 2

July - December 2008

What is the difference between a tough ethical decision and a defining moment? An ethical decision typically involves choosing between two options: one we know to be right and another we know to be wrong. A defining moment, however, challenges us in a deeper way by asking us to choose between two or more ideals in which we deeply believe. Such challenges rarely have a "correct" response. Rather, they are situations created by circumstance that ask us to step forward and, in the word of the American philosopher John Dewey, "form, reveal, and test" ourselves. We form our character in defining moments because we commit to irreversible courses of action that shape our personal and professional identities. We reveal something new about us to ourselves and others because defining moments uncover something that had been hidden or crystallize something that had been only partially known. And we test ourselves because we discover whether we will live up to our personal ideals or only pay them lip service.

Joseph L. Badaracco, Jr

The Discipline of Building Character, p. 116 Harvard Business Review, March-April 1998 